\title{
Youth Negotiation of Citizenship Identities in Pakistan: implications for global citizenship education in conflict-contexts
}

\author{
Laila Kadiwal $^{\mathrm{a}}$ and Naureen Durrani ${ }^{\mathrm{b}}$ \\ ${ }^{\text {a }}$ University of Sussex ${ }^{1}$, UK \\ ${ }^{\mathrm{b}}$ University of Sussex ${ }^{2}$, UK
}

\begin{abstract}
This study explores young students' negotiation of their citizenship identities at the intersection of their class, gender, religious and ethnic identifications in the conflict-affected setting of Pakistan. While much of the global literature on global citizenship education (GCE) primarily takes into account the perspectives of middle-class or elite students located in richer economies, the current study is centered on a socio-demographically diverse group of young people in a low-income setting. With a specific focus on their negotiation of issues around diversity and justice, students' narratives generated important recommendations for a transformative and historically-nuanced postcolonial/decolonial approach to global citizenship engagement that should be considered more broadly. The study illuminates the ways the global / local historical, cultural, political and economic factors influence individual relationship with GCE and offers useful pedagogical and policy implications for GCE 'from below'.
\end{abstract}

\section{Keywords}

Global citizenship education; Pakistan; religion; peace education; postcolonial; youth

\section{Introduction}

GCE has been advanced by the UN to constitute a vital part of its Preventing Violent Extremism through Education Strategy (Biccum, 2018). It is considered that soft measures such as education must accompany hard counterterrorism measures such as policing and military interventions (Biccum, 2018). The discourse around youth's vital role in positively transforming conflict situations and building peace emerged in Pakistan in the wake of 9/11 as part of the USA-led 'War on Terror' (Durrani et al. 2016). Increasingly in Pakistan, global actors are shaping the design of educational interventions and policies, acknowledging the significance of teaching students about their responsibilities within the global context. In 2017, the revised draft of the National Education Policy of Pakistan declared its aspiration to educate young people who are aware of their 'obligations to contribute constructively towards

\footnotetext{
${ }^{1}$ The author has moved to the Institute of Education, University College London.

2 The author has moved to Nazarbayev University Graduate School of Education.
} 
the global community' (MoE, 2017, 57). This step also resonates with UNESCO's $(2014,10)$ move to see global citizenship as a 'framing paradigm' for the Post-2015 education agenda. The international interest in GCE raises questions about the extent to which voices of young Pakistanis are reflected within its discursive framework. This study examined how students negotiated civic agency at the intersection of their class, gender, religious and ethnic identifications in Pakistan and its implications for GCE.

This study makes three contributions to existing scholarship on GCE. First, much of the global literature on GCE primarily takes into account the perspectives of relatively privileged students located in more prosperous economies, whereas, the current study is centered on a socio-demographically diverse group of young people in a low-income setting. Second, there is limited understanding of the ways the global/local historical, cultural, political and economic factors influence the individual relationship with GCE in conflict-contexts. This article advances our understanding of how these intersections interact with young peoples' attitudes to citizenship. Third, students' narratives generated significant recommendations for a more critical, transformative and historically-nuanced postcolonial/decolonial approach to global engagement, which differs from the mainstream manifestations of global citizenship in Pakistan and as such offers useful pedagogical and policy implications for GCE 'from below'.

This article is organised into five sections. We first map the scholarship on GCE by distinguishing between soft and critical approaches to GCE and how soft approaches fail to mitigate inequities and conflict. Second, we explain a theoretical and analytical framework that represents a transformative agenda. The third section applies this framework to illustrate the context of Pakistan. The fourth clarifies the methodological choices and challenges in applying this framework to the study of Pakistan. The fifth section then engages with the findings in light of broader literature. The study concludes by briefly setting out some ways forward for thinking about the issues of GCE in educational policymaking in Pakistan.

\section{Mapping the GCE discourse}

Broadly, the GCE discourse assumes that in this era of greater mobility and connectivity, contemporary nation-centric approaches to citizenship education are no longer suitable and there is a need to inculcate a global worldview among national citizens (Pashby, 2008). A universal approach to GCE does not exist. Two issues central to GCE debates include diversity and justice (Davies et al., 2018). These two concerns problematise the question of who can be a 'global citizen.' Questions have been raised from across the political spectrum: some suspect whether GCE privileges a few, the others wonder whether it is a 'secular conspiracy' (Schattle 2008). Other scholars have deliberated on the meaningfulness of the concept of 'global citizen' in the absence of global governance structures (Bates, 2012). Many scholars think that current ideas of national citizenship need to expand, others believe that our very conceptions of the modern nation-state need to be revised to encompass complexities of global citizenship (Pashby, 2018). 
Some useful typologies have emerged to make sense of different approaches to GCE (e.g., Banks, 2004; Shultz, 2007; Schattle, 2008; Dill, 2013; Oxley and Morris, 2013; Andreotti, 2014; Stein, 2015). These typologies range from hegemonic models on the one hand to critical approaches, on the other. Andreotti (2006) distinguishes between the soft and critical approaches to GCE. Andreotti $(2014,13)$ observes that there are at least two broader trends in education that promote concern for the 'distant others.' The soft approaches are grounded in the idea of 'common humanity,' and critical approaches are rooted in the ideas of 'justice and complicity in harm.' The soft GCE represents more conventional forms of global citizenship. They privilege charity and compassion over advocating for political responsibility for the roots of inequities (Andreotti, 2006). Within soft approaches, entrepreneurial and liberalhumanist paradigms dominate. The economic paradigm assumes that accumulation of universal knowledge will lead to the country's competitiveness in the global economy. In the liberal-humanist paradigm, GCE works with ideas of universal human progress determined by global and national representatives (Andreotti, 2014).

In conflict-affected societies, such as Pakistan, the term GCE is a relatively recent arrival (Quaynor, 2012; Goren et al., 2017). Predominant manifestations of global citizenship involve soft education approaches, mainly entrepreneurial and liberal-humanist interventions. While entrepreneurial discourse of global citizenship sees GCE as a tool for enabling students to become competitive workers for the global economy (Dill, 2013), liberal-humanist approaches see peace education as imperative to bridge divided and diverse societies (Reilly and Niens, 2014). Peace education appears in multiple versions interested in, 'common ground,' tolerance, mutual understanding, dialogue, multicultural education, human rights, and respect for diversity (e.g., Pigozzi, 2006; McGlynn and Zembylas, 2009; UNESCO, 2014). Pakistan privileges soft strategies. In National Education Policy 2009, the global citizen essentially means a global market-based citizen (Pasha, 2015). Pakistani policymakers consider producing citizens who are capable of competing in a 'global knowledgebased economy and information age' as the aim of education (Nasser, 2012, 7).

These approaches do not attend to the issues of power, racism, colonisation and ongoing structures of exploitation (Khoo, 2011). They produce 'change agents' that operate within the existing global economic structure (Biccum, 2018).

It is in the above context, a growing number of scholars have demanded more critical, politicized, and historicized approaches to global engagement (Stein, 2015). For them, GCE denotes a more transformational agenda. The main preoccupation of these discursive approaches is that GCE must enable students to resist and disrupt the existing patterns of inequalities. Transforming global/national economic, political and structural conditions of conflict is seen as essential for peacebuilding (Novelli et al., 2017). There is also a call for learning to work for social justice in global/local contexts (e.g., Banks, 2004; Jorgenson and Shultz, 2012; Andreotti, 2014; Oxfam, 2018), and gender justice (e.g., Arnot, 2009). Similarly, there is a bid for critical approaches to GCE in Pakistan (Dean, 2013, Nasser, 2012, Pasha, 2015, Durrani and Halai, 2018). ${ }^{\text {i }}$ 


\section{Theoretical framework}

Given that Pakistan is a postcolonial context, our contributions to the GCE debate have focused on the use of postcolonial/decolonial theories as analytical tools for analysis. These approaches to GCE question whether the soft approaches are a new form of imperialism that reproduce existing global imbalances (Andreotti, 2014, 2016). Spivak (1988) argues that discourse of modernisation deliberately ignores colonisation, perpetuating assumptions that it has no relevance for contemporary global issues and in the creation of the wealth of the 'First World' today. It is this ideology that creates the discourse of 'development.' Here, poverty is constructed as a lack of the right skills, knowledge, attitudes, and competence rather than as a lack of control over the means of production. Kapoor $(2014,1126-7)$ elaborates that the powerful Western states engineered 'imperialist amnesia,' to invent the image of the West as a benevolent 'First World' willing to give 'aid' and expertise to underdeveloped 'Third World.' Spivak (2004) argues that in the mainstream narratives of development/modernity, the historical and contemporary violence is deliberately concealed so that the 'Others' can be exploited at the intersections of geographical location, class, race, and gender of Western humanism (Spivak, 2004). The above ideological tendency is reflected in mainstream models of GCE. Andreotti $(2006 ; 2011 ; 2014)$ notes the economic paradigm of GCE view an economically ascendant North as the role model which exports expertise for the economic development of the countries seen as falling behind. Similarly, in the mainstream liberalhumanist paradigm, global and national elites determine the notion of universal progress in ways that serve the agendas of the donors.

Dominant ideas of GCE are deeply embedded in the normative Western conceptions of the world, marginalising alternative understandings (Stein, 2015). Grosfoguel $(2013,75)$ contends that the dominant epistemologies of knowledge production demonstrate 'epistemic racism and sexism.' The knowledge produced from the social/historical experiences of people from the locations defined as 'non-Western,' are considered as "inferior" in relation to the "superior" knowledge produced by the few Western men of five countries', namely, France, England, Germany, Italy, and the USA. Additionally, knowledge produced by women whether Western or non-Western is also considered inferior. Santos (2007) identifies this modern Western thinking as 'abyssal', which consists of visible and invisible distinctions that determine one part of humanity, on this side of the line, as human and another part of humanity, on the other side, as sub-human. The other, sub-human, side is sacrificed to sustain the universality of humanity on this side of the line. For Santos (2007) this violence of epistemologies constitutes 'epistemicide.' The ideologically selective discourse of modernity thus produced the binary of the 'Third World/ First World' in which the image of the Western 'self' was mainstreamed as civilised, rational, strong, modern, secular, active, and superior, and the non-Western 'other' as barbaric, irrational, weak, backward, religious, passive, and inferior (Said, 1978; Spivak, 2004).

A postcolonial/decolonial approach to GCE seeks to remedy the unequal distribution of vulnerabilities, oppression, and suffering. MaldonadoTorres (2007) speaks of addressing 'epistemic racism' by creating space for historically subjugated people to speak in their terms. 
Similarly, Santos (2007) calls for 'global cognitive justice': space for subjugated peoples to contribute transformative knowledge. Andreotti (2006), however, bids for going beyond a simplistic binary of North-South relations, demanding global political accountability for inequities. For her $(2006,44)$, the South is not merely 'a site for Western forceful dominance or some 'grassroots' resistance'. Biccum (2018) also asserts that we need to engage with global imperial history, including the European imperialism, American empire argument, the Caliphate and other manifestations of imperial projects worldwide. Thus, postcolonial influences emphasise everyone's complicity and investments in harm (Andreotti, 2012). A global citizen should feel inclined to act on global issues (Stein, 2015). 'Outrage' at social injustice must be felt so strongly that one feels compelled to take action (Davies, 2006). In this article, we employ postcolonial/decolonial theories as a useful analytical framework for understanding the experiences of Pakistani young people, who inhabit the other side of the 'abyssal' line in the geopolitical economy of knowledge production.

\section{Students and global citizenship in conflict-contexts}

There is a small but growing body of scholarship examining young people's perceptions of citizenship in conflict-contexts (e.g. Myers, 2010; Niens et al., 2013, 2013; Reilly et al., 2014, 2014; Lopes-Cardozo et al., 2015; Goren et al., 2017a, 2017b; Bickmore et al., 2017). It appears that that large proportions of young people, across the world, experience disengagement or exclusion from democratic participation in global problem-solving (Bickmore et al., 2017). Especially in high-conflict contexts, young people's attitudes may not always align with the state's vision of citizenship and national identity (Barton and McCully, 2005; Davies, 2006). They may also hold a variety of different and contradictory views regarding who can be seen as a global citizen (Goren and Yemini, 2017b).

The evidence indicates the impact of students' context on attitudes to citizenship. Yemini and Furstenburg (2018) in the Israeli context found that students from elite backgrounds, based in international schools, tended to place greater emphasis on the rights of individuals, preferring a universalist conception of human rights, whereas elite students from local public schools considered recognition of the rights of minorities and religious groups as more critical. Their pattern of thinking, however, reflected the need to help the poor rather than transform the conditions that reproduced conflict and global inequalities. In contrast, when the voices of young people from diverse contexts were included, they tended to value a transformative approach to global citizenship. For instance, a quantitative survey of 4,245 pupils in England and Wales from diverse backgrounds revealed high levels of student interest in global issues (Davies, 2006). Similarly, Pashby (2018) notes that a proposal prepared by young people, from across diverse contexts in Canada, questioned the roots of inequalities and asked for a revision of educational curricula to move away from hegemonic narratives on global issues to including marginalised narratives. However, their interpretations tended to replicate exalted notions of being Canadian grounded in problematic notions of modernity that were shaped by colonial legacies (Arshad-Ayaz et al., 2017). This evidence shows that despite the awareness of inequities, young people often may not have tools to mitigate the global/local roots of inequities. 
Pashby (2018) wonders whether the ideology of global citizenship education is indeed global. The literature review by Goren and Yemini (2017b) suggests that most empirical studies on GCE were concentrated in developed economies and private or international schools, thereby carrying relatively privileged class assumptions such as access to travel opportunities and contact with people from other national and cultural backgrounds facilitated by online technologies. At the time of writing, we identified only one study on perceptions of global citizenship among students in a private school in Pakistan. Pasha (2015) reports that students did not see themselves as global citizens in the absence of sufficient opportunities to interact with the world. In resonance with Goren and Yemini's (2017b) findings, their notion of global citizenship also reflected the privileged class-based assumptions of mobility and contact with people from other countries and cultures. Therefore, exploring young students' negotiation of citizenship identities from a spectrum of socio-economic, gender and religiously diverse backgrounds in Pakistan speaks to a significant gap in knowledge.

\section{Context}

Mignolo (2011) argues that transcending Eurocentrism warrants attention to the 'darker side of modernity.' Accordingly, we highlight the continuous epistemic, cognitive, structural, economic, cultural and military violence that young people face in Pakistan at the intersection of the global/local processes. Andreotti $(2006,41)$ warns that if we fail to take into account these geopolitical imbalances, "in global citizenship education, we may end up promoting a new 'civilising mission"”.

First, the social, economic and cultural situation of youth in Pakistan, is one of acute globallocal inequities (Najam and Bari, 2017, v). Pakistan is among the top 20 most fragile states in the world (The Fund for Peace, 2018). This situation means that young Pakistanis, nearly 64\% of 200 million populations of Pakistan, are highly susceptible to experiencing violence, the breakdown of institutions, displacement, humanitarian crises or other emergencies (OECD, 2016). This situation is not inevitable; it is the underside of global-national actions. Spivak (1988) urges us to examine the role of colonisation and its impact on poverty and conflict. Under colonial rule, South Asia was subjugated into the global economy as a reservoir of cheap raw materials and labour, and as a market to support Britain's emerging industry (Khan, 1961). Global policies continue to legitimise colonial patterns of dominance over Pakistan. Using debt crisis as leverage, global actors have forced Pakistan to increase taxes on the poorest, reduce taxes on import and open its market to foreign companies (See Bhutta, 2001; Khan et al., 2011). It has also been propped up by autocratic/military governments, supported by the US and the Western world, in return for military government support during the Cold War, and the 'war on terror' (Burde, 2014; JDC, 2018). Spending a significant share of government revenues on servicing debt, means there is little left for health, education and water provision for citizens. While, Islamabad, the capital of ruling elite, has the highest tertiary education completion rate at $42 \%$; Balochistan, the mineral and gas-rich region, at $6 \%$ respectively remains systematically deprived of education (GMR-UNESCO, 2018). Moreover, foreign investors exert control over Balochistan's resources (Gare, 2006; Faiz, 
2015). The situation is not unique to Pakistan as neoliberal accumulation is directly connected with dispossessing the most vulnerable people of resources, income, opportunities, and land, across the world (Harvey, 2009).

Secondly, Pakistan's diversity necessitates a sensitive approach towards unity and diversity, as emphasising one over the other has severe implications for social cohesion. As Banks (2004) notes, 'Unity without diversity results in hegemony and oppression; diversity without unity leads to Balkanization and the fracturing of the nation-state' (cited in Pashby, 2008, 6). Pakistan's population is diverse in socio-demographic terms. Most Pakistanis belong to fluid indigenous ethnolinguistic groups that further vary internally, including Indo-Aryan-Iranian and Turkic-Mongolian languages (e.g., Sindhi, Punjabi, Hindko, Kalasha, Shina, Brushaski, Kashmiri, Pashto, Balochi, Hazargi and Urdu), Dravidian languages (e.g., Brahui) and Tibetan languages (e.g., Balti). Pakistan is also home to diverse faith communities, including Hindus, Sikhs, Buddhists, Kalasha, Christians, and Zoroastrians. While a majority of citizens (96\%) follow Islam, they belong to diverse Muslims communities. Additionally, Pakistan hosts 1.6 million refugees, roughly 10 percent of the world's refugee population (Najam and Bari 2017, 113).

The processes of global-national policies are experienced locally as issues of ethnolinguistic and sectarian conflict (Durrani et al., 2017). The heterogeneous groups of Pakistan experience differential access to state resources, leading to ethnolinguistic insurgencies (Durrani and Dunne, 2010). Pakistan's 'Two-Nation' national narrative portrays Islam and Hinduism as mutually antagonistic religious nations, a theory which, in turn, was invented and naturalised by the British Empire to secure its hold over South Asia (Thaper, 2009). In the 1980s, the USA, Saudi Arabia, and Pakistan promoted a militant vision of Islam to win the war against the Soviet Union (Burde, 2014). These global-local processes have entrenched Wahabi interpretation of Islam, thereby marginalizing diverse Muslim communities (Lall, 2015). The accumulated effects of global-national policies are such that school textbooks promote violence and inequality, glorifying militarisation and war in society (Nayyar and Ahmad, 2003; Durrani and Halai, 2018). Furthermore, curricula in Pakistan promote 'gender injustice.... in ways that foster conflict' (Durrani and Halai, 2018, 36). These issues are not unique to Pakistan but critical in articulating the context within which this study was undertaken.

\section{Methodology}

Data is derived from a larger project aimed at understanding the relationship between education and conflict and how students negotiate civic agency in social cohesion. As such, students' notions of global citizenship emerged implicitly in their narratives.

The research was located in Karachi, the capital city of Sindh province and Pakistan's largest, richest and most socio-demographically diverse city. Karachi alone generates $62 \%$ of national income tax and conducts $95 \%$ of the nation's foreign trading activities, yet nearly $75 \%$ of its nearly 23.7 million inhabitants live on a low-income (Mahbubal Haq Centre, 2014). Karachi's 
apparent economic success is mitigated by violent urban struggles between mafias, land grabbers, politicians and criminals for control of different areas (Ali, 2012). Rivalries between opposing groups make Karachi the prime site for ethnolinguistic, sectarian and political conflict (Durrani and Halai, 2018).

Students represent three different socio-economic, religious and ethnic backgrounds (See Table 1). School A catering to Shia Muslim Mohajir girls was located in a socioeconomically middle-class area. The students' mother tongue was Urdu, while their language of instruction (LoI) was English. School B served lower income Baloch Sunni girls in the peaceful, rural outskirts of Karachi. Students' used Balochi at home, whereas their LoI was Urdu and Sindhi. They had a reasonably good knowledge of Urdu and some knowledge of Sindhi. School $\boldsymbol{C}$ was a government school which catered to the local Sindhi Sunni boys in a volatile urban slum of Karachi. Their LoI and mother tongue was Sindhi. Altogether, the study included 19 young people - five Sindhi boys, eight Baloch and six Mohajir girls between the ages of 15 and 17 studying in secondary schools.

Table 1: Socio-demographic background of research participants

\begin{tabular}{|c|c|c|c|}
\hline Observations & School A $(\mathbf{N}=6)$ & School B (N=8) & School C (N=5) \\
\hline Class & Upper/middle class & Lower middle class-poor & Poor-ultra-poor \\
\hline Gender & Female & Female & Male \\
\hline Ethnicity & Mohajir & Baloch & Sindhi \\
\hline Religion & Shia & Sunni & Sunni \\
\hline Mother tongue & Urdu & Balochi & Sindhi \\
\hline Neighborhood & $\begin{array}{l}\text { Peaceful, mixed, } \\
\text { suburb }\end{array}$ & $\begin{array}{l}\text { Peaceful, Baloch, rural } \\
\text { outskirts }\end{array}$ & $\begin{array}{l}\text { Violence-affected } \\
\text { Sindhi, urban slum }\end{array}$ \\
\hline Migration & $\begin{array}{l}\text { Ancestors had } \\
\text { migrated from India at } \\
\text { the partition }\end{array}$ & $\begin{array}{l}\text { Ancestors had migrated } \\
\text { from Balochistan, one of } \\
\text { Pakistan's province }\end{array}$ & Indigenous \\
\hline School & $\begin{array}{l}\text { Well-resourced, } \\
\text { community-funded, } \\
\text { private }\end{array}$ & $\begin{array}{l}\text { Baloch community } \\
\text { resourced, state school }\end{array}$ & $\begin{array}{l}\text { Highly under- } \\
\text { funded state school }\end{array}$ \\
\hline LoI & English & Sindhi-Urdu & Sindhi \\
\hline
\end{tabular}

We introduced the aims of the study to students in their classes and enrolled them on a firstcome-first-served basis in School A and B. In School C, and the teacher sent an open invitation to students. We enrolled all five students who responded to the call. We conducted participatory focus group discussions. Interviews were mainly conducted in Urdu. In School $\mathrm{C}$, however, discussions combined Urdu and Sindhi languages. Recordings were listened to ensure the accuracy of written translations twice. During the writing process, the recordings were heard again. An analysis of recent National Education Policies (2009 and 2017) and a review of existing literature helped us triangulate the data. Informed by Huberman and Miles' (2002) framework, we derived broader categories based on the initial coding of the transcripts 
and policy texts. We re-categorised the micro-codes, distinguishing between facilitators and barriers to a transformational approach to diversity and equity. It was not always possible to code each student separately, as the focus group involved group work. No schools or students are identified here.

Santos' (2007) metaphor of the 'abyssal lines' discussed earlier offers a useful way of understanding which side we speak from in geopolitical economy of knowledge production. In contrast to a neutral-universalist stance, we have tried to speak with our participants from the other side of the line. As Davies et al. (2018, xxv), assert, 'A plurality of knowledge may allow for cognitive justice.' However, the participants do not have control over the means of knowledge production and cannot represent themselves in their terms (Spivak, 1988). The outcome is the instrumentalisation of participants' voices in ways that leads to representation, which makes us complicit in reproducing inequities. This issue warrants an obligation for 'reciprocal engagement' (Stein, 2015). It has strengthened our commitment to facilitating greater dialogue among young people in Pakistan, our research and the world at large in ways that attend to the issues of power (Khoo, 2011) and further disrupt the reproduction of abyssal thinking in GCE (Andreotti, 2012).

\section{Young people: national identity and global citizenship}

Broadly, participants desired transformation of the current state of affairs in Pakistan and were willing to exercise their agency. Four themes emerged: First, the participants called for political accountability for conflict and inequities. Second, students valued 'unity in diversity,' although, their approaches differed from critical to religiocentric views of citizenship identities. Third, they saw themselves as exercising agency, most visibly, through education. Fourth, students' response to ethnoreligious plurality was neither fixed nor free from their socio-political context.

\section{Political accountability for conflict and inequities}

In contrast to official expectations of young people as obedient citizens (Dean, 2013), our participants demanded political accountability for social, economic, cultural and political structural inequalities. Students perceived successive generations of political elites and society as failing to live up to the promise of freedom, justice and rights. They felt that they, alongside other poor people, refugees, and people of Balochistan, were cast as irrelevant within dominant power relationships, on the other side of the abyssal line. Questions of broader geopolitics and the impact of colonial and neocolonial politics were also raised. The participants expressed a sense that world politics and colonisation had impacted their situation and identified a relationship between conflict and structural inequalities. They wanted redressal of inequalities between different ethnic populations, social strata and provinces. The issue of Balochistan was unanimously singled out, as represented by Mahgul, a Baloch female student (School B) below:

Government has neglected Balochistan. We are told little about Balochistan. The Baloch group is under-represented, neglected and not well developed. 
Male students, in particular, were worried that inequalities had generational impact. Neither government policies, nor textbooks resonated with their needs and lives. They asked for redressing the balance between rich and poor as well as urban and rural. They also felt excluded as their mother tongue Sindhi was accorded less social value than Urdu and English.

\begin{abstract}
This book doesn't say anything about the poor. The book should say that we should build hospitals for poor people. ... It is our duty to look after rural areas and make good doctors available in rural regions. The book should reflect the lives of rural people. They should not only talk about famous people and their struggle only but also of poor people who fought for their nation. (Mohsin, school C)
\end{abstract}

Moreover, participants found themselves disempowered to represent themselves, hold the government accountable and seek justice. They conveyed high levels of belonging to their country but, as Lall (2012) has also noted, felt alienated by the state. They perceived political elites as self-interested individuals 'who are fighting for power and those who have power want more power' (Sanam, school A). They desired transformation of the current state of affairs in Pakistan. The National Human Development Report 2017 that surveyed over 90,000 young people across Pakistan echoed their sentiments: 'Young people in all domains and at all levels, from different geographies and backgrounds, are demanding change' (Najam and Bari 2017, 133).

\title{
Perspectives on unity and diversity
}

A word used frequently by the participants was 'harmony'. Participants' emphasis on hum ahangi (harmony) can be interpreted as concern for a perceived major social crisis. Their approaches varied in terms of how best to bring about harmony among diverse peoples. Students' attitudes ranged from critical to religiocentric views of citizenship. This polarisation mirrors broader contestations between liberal-humanist and religiocentric-nationalist worldviews in Pakistan (see Ahmad, 2008). Nonetheless, even when students adopted a religiocentric perspective on identity, as Kaviraj $(2014,22)$ notes astutely, their 'identities have remained stubbornly plural', allowing possibilities for transformational GCE in Pakistan.

Female students tended to employ a soft approach to diversity. They drew justifications from religious and human rights perspectives. They envisioned Pakistan as a multi-faith, multicultural and multi-ethnic state, with equal rights for every citizen regardless of cultural or communal affiliation or gender. These students' way of belonging to the nation was as grateful Muslims, who framed ideas of respect, tolerance, human rights and peace as religious duties, drawing inspiration from the meaning of Islam as salam, peace. Their vision of openness to the other, was grounded in their communities, as expressed by a student: 
Islam teaches us peace... We need to live in peace. We should not fight on the basis of cultural differences....we should learn from each other and be united. (Salima, school A).

Most of the female students also emphasised that all human beings were equal and had rights, stemming from their common humanity.

We think that everyone has the right to follow their own religion and their own culture. Quaid-e-Azam (Jinnah) also said that every citizen of Pakistan has the human right to follow their own religion. (Naila, school B)

Critical views were also evident. Female students, from school A, in particular, were uncomfortable about the alienating influence of their national ideology on diverse citizens of Pakistan, as expressed by Samira (school A):

The ideology of Pakistan does not recognise cross-border ties. Many Pakistanis have family in India and they don't hate them... The textbook does not recognise that Hindus also have good values and teach their children good values.

Baloch female students also de-emphasized hostilities: 'We should forget what the books say and live happily, that would be the best thing to do' (Golpari, School B).

In contrast, religiocentric tendencies were demonstrated by at least three out of five male students. Drawing on a religiocentric discourse, they believed in the superiority of their own worldview and marked a particular type of religious person as a good citizen (Corsini 1999). Mohsin (school C) said:

Pakistan is based on the "Two-Nation Theory", meaning these (Hindus and Christians) are different from us... We cannot live together. Our religion is far better than other religions.

Similar observations were made by Durrani and Dunne (2010) in a conflict-affected city near the border of Afghanistan with male students viewing their ethnic, religious and national identities as inextricably intertwined.

Male students in the current study believed that differences weakened the harmony among citizens. The two young Sindhi males reflected views similar to liberal-humanist perspectives (e.g. 'Everyone loves their religion and we should respect it') but with the collaborative context of the group, their views were undermined by the other three male students. In the exclusivist approaches, harmony is sought by downplaying differences (Al-Azmeh and Aziz, 2009) as represented by Imran here: 'We don't like to create the differences of Sindhi, Punjabi, and Balochi etc. We should be united as we are all Muslims and are brother of each other.' This narrative of unity excluded religious minorities and women. It also undermined the minority of inclusive voices within their peer group. 
Nevertheless, our conversations with the boys revealed deep-rooted contextual resources for transformational GCE. They were, at the time, commemorating the memory of a locally revered Sufi saint, Bulleh Shah, many of whose poems can stir pluralist sensibilities. The first author was invited to celebrations that emphasised a pluralistic and humanistic vision. They expressed their delight that a 'nice Indian teacher' had visited and listened to them, welcoming the first author as 'their honoured guest', and requested her to stay and teach in their school, despite her national, gender, ethnic and religious difference from them. Indeed, in the majority of participants' cases, as Kaviraj (2014, p. 23) highlights, despite the state's efforts there 'still exists' in South Asia, 'long-term historical commonalities which people spontaneously practice and enjoy — in food, material culture, literature, art'. This humanistic and intercultural strength offers the possibility for reconciliation between the warring nations of South Asia and beyond.

\section{Agency and education}

Transformative GCE posits that a global citizen should feel 'outrage' at social injustice so strongly that they feel compelled to take action (Davies, 2006). An essential element in transformative GCE is agency - the extent to which young people have the capacity to actively participate in the struggle for justice and social transformation (Lopes-Cardozo et al., 2015). Students felt they were exercising agency most visibly through pursuing their education against perceived risks. They assumed it was incumbent upon them to make Pakistan a better place, with education enhancing their ability to do so. However, male students in our sample faced acute hurdles:

My parents, my older brothers say give up your education and work. ... I say, please just give me two months, three months, I am trying anyhow to at least finish my matriculation. (Salim, school C)

Although families and friends discouraged them from pursuing their education, the participants believed that obtaining matriculation would transform their fate. They noted that receiving some education had already had a positive impact on their wellbeing and had strengthened their ability to help families and communities. Leaving behind 'gambling, fighting and, stealing' had also increased their self-esteem.

Female students, conversely, highlighted that terrorism had a serious impact on their wellbeing and freedom. One of their classmate's father had been killed a few weeks ago, an incident which had shaken their morale and discouraged their classmate from leaving her home. They expressed:

Peace is freedom to go to school without the fear of death, our or families' death. (Sara, school A)

Statistics show that 1 out of every 4 young Pakistanis had been a victim of violence or had family or friends who were victims in 2013 (Najam and Bari 2017, 113). Furthermore, Pakistan has experienced high numbers of targeted attacks against educational 
institutions, students and teachers (Durrani et al., 2017). Despite the dangers, the participants believed they were brave by confronting their fears and attending school. They drew inspiration from their religion, that striving for education was the right thing to do in their situation.

Furthermore, youth demonstrated an immense sense of volunteerism (e.g. planting trees, helping neighbors, rescuing dogs, etc.). For instance, during recent natural disasters youth from across Pakistan, from diverse backgrounds, mobilised in large numbers to organise rescue and relief efforts (Najam and Bari, 2017). Unquestionably, a majority of the participants were not passive; they cared about political participation and were troubled by the state of inflation, employment, education, healthcare, and poverty. They also felt concerned about corruption, terrorism, the energy crisis and water situation.

However, the participants' agency was undermined by the lack of distributive, recognition and democratic justice (Fraser, 2007), which, as Andreotti (2014) and Stein (2015) emphasise, curtails 'freedom to choose' and autonomy to take action for social justice. Despite their best efforts, as per the national trend, the Sindhi young men were likely to drop out - merely $6 \%$ manage to complete upper secondary level; Baloch females had $0 \%$ chance of proceeding to higher education and the Urdu speaking females had relatively better chances at a $21 \%$ national average of completing upper secondary level (GMR-UNESCO, 2018). In this sense, their being able to exercise their active citizenship through education, was undercut by class, location and ethnic stratification. Although they believed in the constructive face of education, in Pakistan education is one of the key sites of reproducing inequities and conflict (Lall, 2015). Moreover, the national education does not promote active participation in democratic life (Dean, 2013), or inculcate critical consciousness (Naseer, 2012). Thus, participants had a sense of outrage and the desire to take action but limited capacity for transforming power relations and little access to education that enabled them to do so.

\section{Contextual influences on perceptions of diversity and equity}

Studies suggest that students' lived experiences inform how they conceptualise citizenship/global citizenship identities (Bickmore et al., 2017). This observation was applicable to our participants as their positioning was influenced by the way conflict and education intersected with their social class, school type, neighborhood, gender, migration, ethnolinguistic and religious backgrounds in their everyday lives. The Mohajir female students from school A, although socioeconomically affluent, were part of religiously marginalised Shia Muslim communities in Pakistan. Female students of school B, contrastingly, although Sunni-majority, hailed from socioeconomically and politically marginalised Baloch communities also were caught up in fragility. Thus, each experienced issues of marginalisation in distinct ways and valued respect for diversity. Moreover, the female students appeared to have greater access to resources than the Sindhi male participants. Their communities were heavily invested in their education, and their teachers valued an inclusive view of identity. They lived in the relatively peaceful areas of Karachi and 
studied in a combination of English, Sindhi and Urdu languages so had a greater linguistic facility. Also, their schools employed teachers from Baloch, Mohajir and Sindhi backgrounds, providing greater opportunities for intercultural interactions. Students' migration background also influenced their relationship with the 'other.' The ancestors of Urdu-speaking Mohajir female students had migrated to Karachi from India at the time of partition, and they still had relatives in India. They searched for information on the Internet and watched documentaries that offered them multiple and alternative perspectives to 'official' textbooks.

Contrastingly, the Sindhi Sunni male students were deprived of these freedoms to live in a relatively stable, resourceful and supportive learning environment. They were growing up in a volatile urban slum that threatened everyday survival due to ongoing gang violence and police raids. Their dilapidated school was run by one dedicated male teacher, who taught grades 1 to 9 in an adult-centered, top-down approach. The students worked part-time as labourers or fishermen, often dropping in and out of school, to sustain themselves. Further factors eroded their resources: They felt excluded as their mother tongue Sindhi was accorded less social value. Preachers from Saudi Arabian affiliations delivered fiery speeches regularly against religious minorities in the neighborhood. Furthermore, according to our gatekeepers, Sufi shrines were being closed at the time of fieldwork, further eroding spaces that historically promoted a pluralistic vision. There also appeared growing socio-economic hostilities between Hindu Sindhis and Muslim Sindhis, who had co-existed for centuries, leading to the migration of the Hindu Sindhis from the area. The echoes of loss of intercultural space and socio-economic grievance can be heard in Sahil's observation:

In our childhood, some Hindus lived near our home. They celebrated Holi and all their festivals. We also used to go to their celebrations as they used to invite us. We used to eat together... In Pakistan, there are lots of Hindus, mostly shops belong to Hindus... Their children go to private schools.

They also felt threatened by Islamophobic propaganda in the West, which seemed to further wear down their transformational potential. This experience shows that international, national, and local interactions create new patterns of inclusion and exclusion (Eidoo et al. 2011). It appeared that socio-economic and political grievances, a heightened sense of threat and the struggle for everyday survival, along with increased exposure to Wahabi ideologies had pushed the Sindhi boys towards adopting a more religiocentric discourse, perhaps as a way of staying resilient in an otherwise hopeless situation. This situation increases their vulnerability as studies indicates that militant narratives capitalise on deprivation and grievances (Najam and Bari, 2017).

In summary, participants' response to ethnoreligious plurality cannot be seen as free from their cultural-political-economy context, and static throughout their lives. They exaggerated difference, as in the case of male students, in times of threat and tension and stated similarities when ecumenism was wanted as in the case of the female students. These students had very differential access to resources and varied experiences of empowerment / disempowerment and they demonstrated attitudes to diversity that ranged from critical to religiocentric 
perspectives. They were drawing selectively from both school curricula and lived experiences to support a range of developing and flexible identities.

\section{Conclusion}

This study explored young students' negotiation of their citizenship identities at the intersection of their class, gender, religious and ethnic identifications in the conflict-affected setting of Pakistan. Their narratives generated significant recommendations for a transformative form of GCE, that takes a specific focus on the themes of diversity and justice. Rather than asking for humanitarian help and charity, the young people demanded transformation of conditions that produce poverty and conflict. In this sense, while they may have failed to identify themselves as global citizens (Pasha, 2015), they exercised critical global citizenship. Second, students were seriously concerned about the social fragmentation they perceived in their society. Although their approaches differed from critical to religiocentric views of citizenship identities, there prevailed repertoires of humanistic and intercultural resources, which offered a remarkable possibility for reconciliation among divided communities. Third, participants expressed a sense of outrage and the desire to take action, but had limited capacity for transforming the roots of inequities and conflict. They believed in the power of education to enable them to do this and strived for it, sometimes risking their lives. However, education itself, as discussed by participants and attested by broader research, is a major enabler of inequities and conflict. Fourth, students' positioning appeared to be influenced by the way conflict and education intersected with their social class, school type, neighbourhood, gender, migration, ethnolinguistic and religious backgrounds. Due to these complexities, it was difficult to ground their experiences in any single marker of their identity. Indeed, as Pashby (2018) notes, identities are dynamic, complex, and overlapping; therefore, no single marker of identity can be foregrounded.

\section{Implications}

First, the current manifestations of GCE in Pakistan would need re-thinking. The prevailing liberal-humanist narratives of peace education in Pakistan, as Higgins and Novelli $(2018,48)$ observe in the context of Sierra Leone and elsewhere in conflict-contexts, risk distracting attention away from the structural drivers of injustice and long-term conflict in the country. These approaches 'ultimately privilege an international peace agenda over the contextspecific lived realities of its target audiences...'. Similarly, the current notions of a marketbased global citizen in Pakistan help those already advantaged. With the idea of neoliberal individualism as global citizenship, well-resourced individuals from rich economies with unlimited mobility claim access to the resources of the world with a sense of entitlement (Sant et al., 2018), while young people of Pakistan, are taught their place in the global labour market (Wallerstein, 2004). In contrast, transformative and historically-nuanced approaches to global engagement that draw upon postcolonial/decolonial lenses would enable students to think about the roots of global/local historical, political, economic and socio-cultural dimensions of conflict and inequities. Biccum (2018) correctly observes that GCE cannot contribute to counterterrorism efforts unless it embodies the decolonial approach to 'cognitive justice'. An honest global conversation about the role of historical, military, economic, 
political and structural violence in shaping our contemporary situation is needed. If we neglect to do this, a global citizen will be expected to remain ignorant of how colonialism continues to manifest itself and of one's complicity in it (Andreotti, 2014), and a small elite group will continue to assume responsibility to achieve 'progress' for all (Arshad-Ayaz et al., 2017).

Second, the prevailing narrative of national identity in Pakistan also needs revisiting. Drawing upon Panjwani's (2017) insight on 'religification,' it is evident in the case of Pakistan that the absolutisation of one identity marker over others is empirically unsound and detrimental to the young generation's sense of self and other. It creates an artificial discourse of difference between communities, a binary that tears social fabric. Students' repertoire of humanistic and intercultural resources offers a strong possibility for reconciliation among communities. If we do not draw upon their peace resources, we risk 'misunderstanding' the ordinary young Pakistanis, as lacking 'correct' subjectivities, knowledge and attitudes to coexist as global citizens while allowing the powerful elites to escape political accountability for promoting justice. GCE may remain grounded in liberal-humanistic discourses coexisting with colonialist assumptions about difference (Pashby, 2008), and the abyssal lines of colonialism will continue to construct binaries of the Western civilized 'self' versus the barbaric 'other' in the context of Pakistan.

Given the participants' desire for transformation of the current state of affairs in Pakistan and their willingness to exercise their agency, we are optimistic that young Pakistanis can play a vital role in positively transforming conflict situations and building peace. If young Pakistanis' perspectives were included in GCE and broader policymaking around this, it would prepare the ground for 'cognitive justice'. It will also help create space for young Pakistanis subjugated by colonial/neocolonial violence to envision their solutions and futures in their terms. This approach will contribute substantially to the UN's aspirations for peace and democracy.

\section{Disclosure statement}

No potential conflict of interest was reported by the authors.

\section{Acknowledgement}

This publication draws on a study funded by UNICEF, New York [G1563], with Prof Mario Novelli as Co-Director of the Research Consortium on Education and Peacebuilding. The views expressed herein do not reflect those of the UNICEF and their partners. We are grateful to the youth who took part in this study and the Aga Khan University, Pakistan who was our collaborating partner.

\section{References}


Ahmad, Iftikhar (2008), The Anatomy of an Islamic Model: Citizenship Education in Pakistan, 97-109, in: Citizenship Curriculum in Asia and the Pacific. Springer.

Ali, Mubarak. 2002. 'History, Ideology and Curriculum'. Economic and Political Weekly 37 (44/45): 4530-31.

Ali, Zulfiqar. 2012. 'Violence in Karach: Is It Political, Ethnic or Religious Conflict?' Pakistaniaat: A Journal of Pakistan Studies 4 (3).

Andreotti, Vanessa. 2016. 'The Educational Challenges of Imagining the World Differently'. Canadian Journal of Development Studies / Revue Canadienne d'études Du Développement 37 (1): 101-12. . 2014. 'Critical Literacy: Theories and Practices in Development Education | Development Education Review'. Development Education Review, no. 19. . 2012. 'Postcolonial and Post-Critical "Global Citizenship Education”'. In Education and Social Change: Connecting Local and Global Perspectives, edited by Geoffrey Elliott, Chahid Fourali, and Sally Issler. A\&C Black. . 2011. '(Towards) Decoloniality and Diversality in Global Citizenship Education'. Globalisation, Societies and Education 9 (3-4): 381-97. . 2006. 'Soft versus Critical Global Citizenship Education'. Development Education Review, 21-31.

Arnot, Madeleine. 2009. 'A Global Conscience Collective?: Incorporating Gender Injustices into Global Citizenship Education'. Education, Citizenship and Social Justice 4 (2): 117-32.

Arshad-Ayaz, Adeela, Vanessa Andreotti, and Ali Sutherland. 2017. 'A Critical Reading of "The National Youth White Paper on Global Citizenship": What Are Youth Saying and What Is Missing?' International Journal of Development Education and Global Learning 8 (2): 19-36.

Al-Azmeh, and Aziz. 2009. 'Pluralism in Muslim Societies'. In In The Challenge of Pluralism: Paradigms from Muslim Contexts, by Abdou Filali Ansary and Sikeena Karmali. Edinburgh: Edinburgh University Press.

Banks, James A. 2004. 'Teaching for Social Justice, Diversity, and Citizenship in a Global World'. The Educational Forum 68 (4): 296-305.

Barton, K.C., and A.W. McCully. 2005. 'History, Identity, and the School Curriculum in Northern Ireland: An Empirical Study of the Secondary Students'. Curriculum Studies, 85-116.

Bates, R. 2012. 'Is Global Citizenship Possible, and Can International Schools Provide It?' Journal of Research in International Educatio 11 (3): 262-74.

Bhutta, Zulfiqar Ahmed. 2001. 'Structural Adjustments and Their Impact on Health and Society: A Perspective from Pakistan'. International Journal of Epidemiology 30 (4): 712-16.

Biccum, April. 2018. 'What Can Counterterrorism Learn from Cognitive Justice in Global Citizenship Education?' International Political Sociology 0: 1-19.

Bickmore, Kathy, Ahmed Kaderi, and Ángela Guerra-Sua. 2017. 'Creating Capacities for Peacebuilding Citizenship: History and Social Studies Curricula in Bangladesh, Canada, Colombia, and México'. Journal of Peace Education, August, 1-28. 
Burde, Dana. 2014. Schools for Conflict or for Peace in Afghanistan. New York: Columbia University Press.

Corsini, Raymond J. 1999. 'Religiocentrism'. In The Dictionary of Psychology. Psychology Press.

Davies, Ian, Ho Li-Ching, Dina Kiwan, Carla L. Peck, Andrew Peterson, Edda Sant, and Yusef Waghid, eds. 2018. The Palgrave Handbook of Global Citizenship and Education.

Davies, Lynn. 2006. 'Global Citizenship: Abstraction or Framework for Action?' Educational Review 58 (1): 5-25.

Dean, Bernadette. 2013. 'Citizenship Education in Pakistan: Changing Policies and Practices in Changing Social-Political Contexts'. In Globalization, the Nation-State and the Citizen: Dilemmas and Directions for Civics and Citizenship Education, 64-79.

Dill, Jeffrey S. 2013. The Longings and Limits of Global Citizenship Education: The Moral Pedagogy of Schooling in a Cosmopolitan Age. 1 edition. Routledge.

Durrani, Naureen, and Mairead Dunne. 2010. 'Curriculum and National Identity: Exploring the Links between Religion and Nation in Pakistan'. J. Curric. Stud. 42 (2): 215-40.

Durrani, N.aureen, and Anjum Halai. 2018. 'Dynamics of Gender Justice, Conflict and Social Cohesion: Analysing Educational Reforms in Pakistan'. International Journal of Educational Development 61: 27-39.

Durrani, Naureen, Anjum Halai, Laila Kadiwal, Salima Rajput, Mario Novelli, and Yusuf Sayed. 2017. 'Education and Social Cohesion in Pakistan. Summary Report'. Research Consortium on Education and Peacebuilding, UNICEF PBEA Programme. Falmer: University of Sussex.

Eidoo, Sameena, Leigh-Anne Ingram, Angela MacDonald, Maryam Nabavi, Karen Pashby, and Saskia Stille. 2011. "Through the Kaleidoscope": Intersections Between Theoretical Perspectives and Classroom Implications in Critical Global Citizenship Education'. Canadian Jounral of Education 34 (4): 59-85.

Faiz, Jalal. 2015. 'Politics of Education, Conflict and Conflict Resolution in Balochistan, Pakistan'. University of Westminister.

Gare, Fredrick. 2006. 'Pakistan: The Resurgence of Baluch Nationalism.' Carnegie Endowment for International Peace 3.

GMR-UNESCO. 2018. World Inequality Database on Education • Pakistan.

Goren, Heela, and Miri Yemini. 2017a. 'Obstacles and Opportunities for Global Citizenship Education under Intractable Conflict: The Case of Israel'. Compare: A Journal of Comparative and International Education 48 (3): 397-413.

. 2017b. 'Global Citizenship Education Redefined - A Systematic Review of Empirical Studies on Global Citizenship Education'. International Journal of Educational Research 82 (January): 170-83. 2017c. 'Global Citizenship Education Redefined - A Systematic Review of Empirical Studies on Global Citizenship Education'. International Journal of Educational Research 82 (January): 170-83.

Grosfoguel, Ramon. 2013. 'The Structure of Knowledge in Westernized Universities: Epistemic Racism/Sexism and the Four Genocides/Epistemicides of the Long 16th Century'. Human Architecture: Journal of the Sociology of Self-Knowledge 11 (1). 
Harvey, David. 2009. 'The "New” Imperialism: Accumulation by Dispossession'. Socialist Register 40 (40).

Higgins, Sean, and Mario Novelli. 2018. 'The Potential and Pitfalls of Peace Education: A Cultural Political Economy Analysis of the Emerging Issues Teacher Education Curriculum in Sierra Leone'. Asian Journal of Peacebuilding 6 (1).

Horner, Lindsey, Laila Kadiwal, N. Durrani, Y. Syed, and M Novelli. 2015. 'Literature Review: The Role of Teachers in Peacebuilding'.

Huberman, Micheal, and Mathew Miles. 2002. The Qualitative Researcher's Companion. SAGE Publications Ltd.

JDC. 2018. 'Jubilee Debt Campaign UK'. Jubilee Debt Campaign UK. 2018.

Jorgenson, Shelane, and Lynette Shultz. 2012. 'Global Citizenship Education (GCE) in PostSecondary Institutions: What Is Protected and What Is Hidden under the Umbrella of GCE?' Journal of Global Citizenship \& Equity Education 2 (1).

Kapoor, I. 2014. "Psychoanalysis and Development: Contributions, Examples, Limits." Third World Quarterly 35 (7): 1120-1143.

Kaviraj, Sudipta. 2014. 'A Strange Love of the Land: Identity, Poetry and Politics in the (Un)Making of South Asia'. South Asia Multidisciplinary Academic Journal, no. 10.

Khan, Mir Mustafa Ali. 1961. 'Pakistan and United Kingdom Trade Relations'. Pakistan Horizon 14 (2): 139-50.

Khan, Rana EjazAli, Muhammad AtifNawaz, and Altaf Hussain. 2011. 'Impact Evaluation of Structural Adjustment Program: A Case of Pakistan'. MPRA Paper. 2011.

Khoo, Su-ming. 2011. 'Ethical Globalisation or Privileged Internationalisation? Exploring Global Citizenship and Internationalisation in Irish and Canadian Universities'. Globalisation, Societies and Education 9 (3-4): 337-53

Lall, Marie. 2012. 'Citizenship in Pakistan: State, Nation and Contemporary Faultlines'. Contemporary Politics 18 (1): 71-86..

Lall, Marie. 2015. 'Community Cohesion and the Role of Education in Pakistan and Bangladesh'. The Heidelberg Papers. Heidelberg: The Department of Political Science of the South Asia Institute, the University of Heidelberg.

Lopes Cardozo, M.T.A, S. Higgins, E. Maber, C.O. Brandt, N. Kushmallah, and M.L.J. Le Mat. 2015. 'Literature Review: Youth Agency, Peacebuilding and Education'. Research Consortium Education and Peacebuilding, University of Amsterdam.

Maldonado-Torres, Nelson. 2007. 'On the Coloniality of Being'. Cultural Studies 21 (2-3): 240-70.

Mahbubal Haq Centre. 2014. 'The Rise of Karachi as a Mega-City: Issues and Challenges.' Islamabad: Mahboob ul-Haq Humand Development Centre.

McGlynn, C., and Michalinos Zembylas, eds. 2009. Peace Education in Conflict and PostConflict Societies - Comparative Perspectives. Palgrave Macmillan US.

Mignolo, Walter. 2011. The Darker Side of Western Modernity: Global Futures, Decolonial. Duke University.

Myers, John P. 2010. “"To Benefit the World by Whatever Means Possible”: Adolescents' Constructed Meanings for Global Citizenship'. British Educational Research Journal 36 (3): 483-502. 
Najam, A., and F. Bari. 2017. 'Pakistan National Human Development Report 2017* Unleashing the Potential of a Young Pakistan'. Islamabad: United Nations Development Programme, Pakistan.

Naseer, Rabia. 2012. 'Citizenship Education in Pakistan'. Pakistaniaat: A Journal of Pakistan Studies 4 (3).

Nayyar, A.H., and Salim Ahmad. 2003. 'The Subtle Subversion: The State of Curricula and Textbooks in Pakistan Urdu, English, Social Studies and Civics'.

Niens, Ulrike, U. O'Connor, and A. Smith. 2013. 'Citizenship Education in Divided Societies: Teachers' Perspectives in Northern Ireland'. Citizenship Studies 17 (1): $128-41$.

Novelli, M, M.T.A Lopes Cardoza, and A. Smith. 2017. 'The 4Rs Framework Analysing Education's Contribution to Sustainable Peacebuilding with Social Justice in Conflict Afected Contexts'. Journal of Education in Emergencies 3 (1).

OECD. 2016. States of Fragility 2016 - Understanding Violence - En - OECD.

Oxfam. 2018. Education for Global Citizenship: A Guide for Schools | Oxfam Education.

Oxley, Laura, and Paul Morris. 2013. 'Global Citizenship: A Typology for Distinguishing Its Multiple Conceptions'. British Journal of Educational Studies 61 (3): 301-25.

Pashby, Karen. 2008. 'Demands on and of Citizenship and Schooling: "Belonging" and "Diversity" in the Global Imperative'. Brock Education 17. . 2018. 'Identity, Belonging and Diversity in Education for Global Citizenship: Multiplying, Intersecting, Transforming, and Engaging Lived Realities'. In The Palgrave Handbook of Global Citizenship and Education - Google Books, edited by Ian Davies, et al.

Pigozzi, Mary Joy. 2006. 'A UNESCO View of Global Citizenship Education'. Educational Review 58 (1): 1-4.

Quaynor, Laura J. 2012. 'Citizenship Education in Post-Conflict Contexts: A Review of the Literature'. Education, Citizenship and Social.

Reilly, J., and U. Niens. 2014. 'Global Citizenship as Education for Peacebuilding in a Divided Society: Structural and Contextual Constraints on the Development of Critical Dialogic Discourse in Schools'. Compare: A Journal of Comparative and International Studies 44 (1): 53-76.

Said, Edward. 1978. Orientalism. Penguin Books India.

Santos, Boaventura de Sousa. 2007. 'Beyond Abyssal Thinking. Eurozine. 2007.

Schattle, Hans. 2008. The Practices of Global Citizenship. Rowman \& Littlefield.

Shultz, Lynette. 2007. 'Educating for Global Citizenship: Conflicting Agendas and

Understandings - ProQuest'. Alberta Journal of Educational Research 53 (3): 248-58.

Spivak, Gaytri. 2004. 'Righting Wrongs'. The South Atlantic Quarterly 103: 523-581.

Spivak, Gaytri. 1988. "“Can the Subaltern Speak?" In Marxism and the Interpretation of Culture, edited by C. Nelson and L. Grossberg, 271-313. Chicago: University of Illinois Press.

Stein, Sharon. 2015. 'Mapping Global Citizenship'. Journal of College and Character 16 (4): 242-52. https://doi.org/10.1080/2194587X.2015.1091361.

Thaper, Romila. 2009. 'The History Debate and School Textbooks in India: A Personal Memoir'. History Workshop Journal, Oxford University Press 67: 87-98. 
The Fund for Peace. 2018. Fragile States Index 2018: Issues of Fragility Touch the World's Richest and Most Developed Countries in 2018 | Fragile States Index.

UNESCO. 2014. 'Global Citizenship Education Preparing Learners for the Challenges of the Twenty-First Century'. UNESCO.

Veugelers, Wiel. 2011. 'The Moral and the Political in Global Citizenship: Appreciating Differences in Education'. Globalisation, Societies and Education 9 (3-4): 473-85.

Yemini, Miri, and Shira Furstenburg. 2018. 'Students' Perceptions of Global Citizenship at a Local and an International School in Israel: Cambridge Journal of Education: Vol 0, No 0'. Cambridge Journal of Education.

i Not all of the literature referred to in this work uses the term 'global citizenship education'. 